\title{
Manajemen Kepemimpinan Profetik \\ Upaya Meningkatkan Kinerja dan Tanggung Jawab Guru di \\ Lembaga Pendidikan Islam
}

\author{
Mohammad Zaini \\ IAIN Jember, Indonesia \\ E-Mail:mohamadzaini12345@gmail.com
}

DOI: https://doi.org/10.21154/sajiem.v2i1.45

\begin{abstract}
Abstrak
Manajemen secara fungsi manajerialnya adalah proses pengelolaan dalam upaya meningkatkan kualitas dan mutu sumber daya yang ada baik manusia maupun sumber pendukung lainnya dengan baik dan benar sebagaimana top porsi masing-masing. Secara kelembagaan khususnya lembaga pendidikan islam kategori pengelolaan baik dan benar manakala dalam prosesnya dapat menumbuhkan tanggung jawab terhadap kinerjanya. Kinerja yang dimaksud adalah kepala sekolah, guru, dan peserta didik bersama-sama berusaha untuk mewujudkan keinginan dan harapan masyarakat seperti kepemimpinan kepala sekolah yang adil dan bijaksana, guru penuh perhatian dan pembimbingan secara inten, karyawan selalu memberikan kemudahan dalam urusan administrasi dan peserta didik saling menghormati satu sama lain. Konteks di atas merupakan salah satu prilaku seseorang yang mengimplementasikan nilai-nilai profetik dalam kehidupannya sehari-hari.
\end{abstract}

Kata kunci: manajemen kepemimpinan, lembaga pendidikan islam, kinerja dan tanggung jawab

\section{Pendahuluan}

Seiring dengan kemajuan informasi dan teknologi, terlebih ketika dihadapkan pada era globalisasi, menurut Dindin Jamaluddin, dunia pendidikan di Indonesia menghadapi tantangan yang sangat serius. Menurutnya; with the current globalization, education in Indonesia faced with enormous challenges. ${ }^{1}$ Penyiapan terhadap generasi penerus bangsa yang berkarakter merupakan kebutuhan yang amat vital, karena karakter yang baik tidak terbentuk

${ }^{1}$ Dindin Jamaluddin, “Character Education In Islamic Perspective", dalam International Journal Of Scientific \& Technology Research, Volume 2, Issue 2, February 2013 ISSN 2277-8616, hlm. 187. 
secara otomatis (good character is not formed automatically). ${ }^{2}$ Hal ini dilakukan untuk mempersiapkan generasi terhadap tantangan global dan daya saing bangsa. ${ }^{3}$

Dalam rangka mempersiapkan tuntutan global tersebut, maka lembaga pendidikan yang tersebar di penjuru Indonesia, khususnya lembaga pendidikan Islam yang berada di tingkat pusat, daerah terus-menerus melaksanakan berbagai upaya peningkatan kinerja dari seluruh komponen madrasah/sekolah agar memiliki competitive adventage (keunggulan bersaing). Tujuan utama peningkatan kinerja ini adalah untuk mewujudkan niat dan tujuan mulia lembaga dalam menciptakan out put peserta didik yang memiliki kemampuan di bidang keimananan, kecerdasan, dan kompetetif serta berakhlak mulia.

Tidak dapat dipungkiri bahwa perkembangan teknologi informasi yang sedemikian cepat tidak saja mengubah cara orang berkomunikasi dan bekerja, namun lebih jauh lagi telah membuat alam persaingan baru. Michael Porter memperkenalkan Five Forces (lima kekuatan) yang harus dicermati oleh pihak pimpinan lembaga pendidikan. Five Forces dapat dijelaskan sebagai berikut : pertama, persaingan antar lembaga pendidikan yang sudah ada (rivalry among existing institution); kedua, ancaman dari lembaga pendidikan pendatang baru (threat of new entrant); ketiga, ancaman dari lembaga pendidikan yang menawarkan jasa pendidikan pengganti (threat of substitute educations service); keempat, kekuatan tawar-menawar pemasok / masyarakat yang membutuhkan jasa pendidikan (bargainning power of suppliers); dan kelima, kekuatan tawar-menawar pembeli (bargaining power of buyer) ${ }^{4}$

Berangkat dari hal tersebut, dapat diketahui bahwa lembaga pendidikan Islam akan memiliki competitive adventage (keunggulan bersaing) jika manajamen kepemimpinannya - di samping aspek yang lain - dikelola dengan baik, sesuai dengan situasi dan latar yang mengelilinginya. Dari fenomena gamabaran di atas, maka makalah ini di fokuskan pada hal-hal berikut ini: Pertama. Bagaimana Konsep manajemen kepemimpinan. Kedua, Bagaimana tipologi kepemimpinan dalam manajeman. Ketiga. Bagaimana pemimpin dalam meningkatkan kinerja guru di lembaga pendidikan islam. Keempat. Bagaimana kepemimpinan berparadigma profetik dalam upaya meningkatkan kinerja guru dan tanggungjawabnya.

\section{Metode Penelitian}

Berdasarkan uraian dan paparan secara teoritis dan konseptual, maka peneliti dalam penelitian ini menggunakan pendekan studi pustaka dengan mendeskripsikan bebebrapa teori-teori yang ada kaitannya dengan konteks lembaga pendidikan di Indonesia khususnya lembaga pendidikan islam.

\section{Hasil dan Pembahasan}

\section{Pengertian Manajemen Kepemimpinan}

Manajemen merupakan suatu proses/ilmu untuk merencanakan, mengorganisasikan, memimpin, dan mengendalikan upaya organisasi dengan segala aspeknya agar tujuan organisasi tercapai secara efektif dan efisien. ${ }^{5}$ Pada hakikatnya, manajemen merupakan proses penggunaan sumber daya secara efektif untuk mencapai sasaran atau tujuan tertentu. ${ }^{6}$ Malayu S.P.Hasibuan berpendapat bahwa manajemen merupakan ilmu, seni yang mengatur proses pemanfaatan sumber daya manusia beserta sumber-sumber lainnya secara efektif dan efisien

\footnotetext{
${ }^{2}$ Aynur Pala, The Need For Character Education, dalam International Journal Of Social Sciences And Humanity Studies Vol 3, No 2, 2011 ISSN: 1309-8063 (Online), hlm. 23.

${ }^{3}$ Weinata Sairin, Pendidikan yang Mendidik, (Jakarta : Yudhistira, 2001), hlm. 211.

${ }^{4}$ E. Rochaeti, Rahayuningsih, Pontjorini dan G.P. Yanti, Sistem Informasi Manajemen Pendidikan, (Jakarta: Bumi Aksara, 2006), hlm. 17-20

${ }^{5}$ Nanang Fattah, Landasan Manajemen Pendidikan, (Bandung: PT Remaja Rosdakarya, 2004), hlm.

1.

${ }^{6}$ Muhaimin, dkk, Manajemen Pendidikan : Aplikasi dalam Penyusunan Rencana Sekolah Madrasah, (Jakata : Kencana, 2009), hlm.. 4
} 
untuk mencapai suatu tujuan tertentu. ${ }^{7}$ Sedangkan menurut Stoner sebagaimana dikutip oleh Handoko manajemen adalah proses perencanaan, pengorganisasian, pengarahan dan pengawasan terhadap kegiatan yang dilakukan oleh para anggota organisasi dan penggunaan sumber daya organisasi lainnya agar mencapai tujuan yang telah ditetapkan. ${ }^{8}$

Secara fungsinya, proses manajemen terlibat beberapa komponen pokok yang ditampilkan oleh seorang pimpinan, yaitu; perencanaan (Planning), pengorganisasian (Organizing), pemimpinan (Leading), dan pengawasan (Controlling). Sedangkan menurut Usman, ${ }^{9}$ fungsi manajemen meliputi; perencanaan, pengorganisasian, pengarahan dan pengendalian. Oleh sebab itu, manajemen diartikan sebagai proses merencanakan, mengorganisasi, memimpin, dan mengendalikan upaya organisasi dengan segala aspeknya agar tujuan organisasi tercapai secara efektif dan efisien..$^{\circ}$ Manullang berpendapat bahwa dalam manajemen terdapat unsur perencanaan, pembuatan keputusan, pengorganisasian, dan penyempurnaan. "Sedangkan menurut Ngalim Purwanto meliputi ; perencanaan, organisasi, koordinasi, komunikasi, supervisi kepengawasan-pembiayaan dan evaluasi. ${ }^{12}$

Berbagai pendapat di atas, secara implisit dan fungsi manajemen pada hakikatnya sebagai berikut ; Perencanaan (planning) : budgeting, programming, decision making, forcasting. Pengorganisasian (organizing) : structuring, assembling resources, staffing. Penggerakan (actuating) : coordinating, directing, commanding,motivating, leading, stimulating, motivating. Pengawasan (controlling) : monitoring, appraising, evaluating, reporting. ${ }^{13}$

Ditinjau dari aspek kebahasaan, kepemimpinan dapat diterjemahkan dalam bahasa inggris leadershif. Istilah leadershif sendiri berasal dari kata leader artinya pemimpin (orang yang memimpin) atau to lead artinya memimpin. ${ }^{14}$ Dalam beberapa kajian teoritis terdapat beberapa definisi yang berkenaan dengan berkenaan dengan kata kepemimpinan (leadership). Keragaman definisi yang berkenaan dengan kepemimpinan, menurut Wahjosumidjo boleh jadi dipengaruhi oleh para peneliti sendiri yang memberikan definisi berbeda berdasarkan pandangan pribadi mereka dan aspekaspek fenomena dari kepentinganyang paling baik bagi para peneliti yang bersangkutan. ${ }^{15}$

Sarros dan Butchatsky, berpendapat bahwa kepemimpinan atau leadership adalah "defined as the purposeful behaviour of influencing others to contribute to a commonly agreed goal for the benefit of individual as well as the organization or common good". Menurut definisi tersebut, kepemimpinan dapat didefinisikan sebagai suatu perilaku dengan tujuan tertentu untuk mempengaruhi aktivitas para anggota kelompok untuk mencapai tujuan bersama yang dirancang untuk memberikan manfaat individu dan organisasi. ${ }^{16}$

${ }^{7}$ Malayu S.P Hasibuan, Manajemen Dasar, Pengertian dan masalah, (Jakarta : Bumi Aksara, 2001), hlm. 2.

${ }^{8}$ T. Hani Handoko, Manajemen, (Yogyakarta : UGM, 2003), hlm. 8. Lihat juga : James A.F. Stoner, Management (New York : Frentice / Hall International, Inc, Englewood, 1982), hlm. 8.

${ }^{9}$ Husaini Usman, Manajemen : Teori, Praktik dan Riset Pendidikan, (Jakarta: Bumi Aksara, 2010), hlm.15

${ }^{10}$ Nanang Fattah, Landasan Manajemen Pendidikan., hlm. 2.

${ }^{11}$ M. Manullang \& Marihot Amh Amnullang, Manajemen Personalia, (Yogyakarta : Gajah Mada University Press, 2008), hlm. 4. hlm. 14

${ }^{12}$ Ngalim Purwanto, Administrasi dan Supervisi Pendidikan , (Bandung : Remaja Rosdakarya, 2010),

${ }^{13}$ Hendyat Soetopo, Manajemen Pendidikan, (Malang : Universitas Negeri Malang, 2001), hlm. 4.

${ }^{14}$ Lihat, John M. Echols dan Hasan Sadily, Kamus Ingris-Indonseia (Jakarta: PT Gramedia, 1996), 351. Kemudian, lihat juga Ahmad Kurnia El-Qarni, Leadershif Dalam Organisasi Perusahaan, (Online). http://www.w3c.org/TR/1999/REC-html. (Diakses 1 Mei 2018)

${ }^{15}$ Wahjosumidjo, Kepemimpinan Kepala Sekolah: Tinjauan Teoritik dan Permasalahannya (Jakarta: PT RajaGrafindo Persada, 2005), 16.

${ }^{16}$ Pendapat serupa juga disampaikan oleh Susilo Martoyo bahwa kepemimpinan adalah "keseluruhan aktivitas dalam rangka mempengaruhi orang-orang agar mau bekerja sama untuk 
Sedangkan menurut Carter V. Good yang dikutif H.A. Malik Fadjar menyatakan bahwa "leadership is the ability and readness to inspire, guide, direct, or manage other." Artinya kepemimpinan merupakan kemampuan dan kesiapan untuk memberikan semangat, membimbing, mengarahkan atau mengatur orang lain. ${ }^{17}$

Dari beberapa pengertian di atas dapat disimpulkan bahwa, manajemen kepemimpinan adalah kegiatan mempengaruhi perilaku orang lain agar mau bekerjasama untuk mencapai tujuan tertentu. Artinya, kepemimpinan dalam organisasi diarahkan untuk mempengaruhi orang-orang yang dipimpinnya, agar mau berbuat seperti yang diharapkan ataupun diarahkan oleh orang yang memimpinnya.

\section{Tipologi Kepemimpinan dalam manajemen}

Secara teoritis terdapat berbagai pandangan para ahli dalam bidang kajian ilmu-ilmu sosial yang mengungkapkan tentang tipe-tipe kepemimpinan. Dianataranya pendapatnya Max Weber dalam studi sosiologisnya melihat ada tiga tipe kepemimpinan yaitu: ${ }^{18}$ pertama, tipe Tradisional, yaitu pemegang kekuasaan (otoriter) dalam kepemimpinan yang didasarkan atas keturunan atau warisan. Misalnya karena ayahnya lurah lalu anaknya atau salah satu keturunannya menjadi lurah juga; kedua, tipe karismatis, yaitu pemegang kekuasaan dalam kepemimpinan karena memiliki sifat-sifat karismatis atau kewibawaan; ketiga, tipe Rasional, yaitu pemegang kekuasaan dalam kepemim-pinan yang didasarkan atas peraturan atau undang-undang.

Menurut Lewin, Leppit dan White dalam studi eksperimentalnya yang dikutif oleh Ary $\mathrm{H}$. Gunawan, mengungkapkan tiga tipe kepemimpinan, diantaranya: ${ }^{19}$ Pertama, tipe kepemimpinan otoriter. Tipe kepemimpinan otoriter yaitu tipe kepemimpinan yang menempatkan kekuasaan di tangan atau sekelompo kecil orang-orang yang disebut atasan sebagai penguasa atau penentu yang tidak dapat diganggu gugat. Sementara orang lain sebagai bawahan harus tunduk pada kekuasaannya di bawah ancaman dan hukuman sebagai alat dalam menjalankan kepemimpinannya. Dalam model kepemimpinan otoriter bawahan tidak diberikan kesempatan untuk berinisiatif dan mengeluarkan pendapat. Perintah dan instruksi atasan tidak boelh ditafsirkan, tetapi harus dilaksanakan secara tertib dan konsekuen tanpa kesalahan. Kedua, Tipe kepemimpinan "laissezfaire". Adalah kebalikan dari kepemimpinan otoriter, dengan memberi kebebasan kepada bawahannya untuk mengambil keputusan. Segala sesuatu berjalan sendiri-sendiri sekehendak anggotanya, sementara pemimpin hanya bertugsa sebagai penasihat. Akibatnya sasaran kerja menjadi simpang-siur. Ketiga, tipe kepemimpinan demokratis. Menempatkan manusia sebagai faktor utama dan terpenting. Tipe kepemimpian demokratis merupakan tipe kepemimpinan yang terbuka, segala sesuatu diambil atas dasar musyawarah dengan menjunjung prinsip saling menghargai dan menghormati.

Sementara itu, Ahmad Kurnia El-Qarni menyebutkan beberapa tipologi kepemimpinan yang dimiliki atau dianut oleh seseorang, diantaranya: ${ }^{20}$ Pertama, tipe otokratis. Seorang pemimpin yang otokratis ialah pemimpin yang memiliki kriteria atau ciri sebagai berikut: a) menganggap organisasi sebagai pemilik pribadi; b) mengidentikkan tujuan pribadi dengan tujuan organisasi; c) menganggap bawahan sebagai alat semata-mata; d) tidak mau menerima kritik, saran dan pendapat; e) Terlalu tergantung kepada kekuasaan formalnya; f) dalam

mencapai suatu tujuan yang memang diinginkan bersama". Martoyo, Pengetahuan Dasar Manajemen dan Kepemimpinan, h. 32.

${ }^{17}$ H.A. Malik Fadjar, Administrasi dan Super Visi Pendidikan, (Yogyakarta: Aditya Media, 1993), 24.

${ }^{18}$ Lihat, Fadjar, Administrasi dan Super Visi Pendidikan..........h. 25.

${ }^{19}$ Ary H. Gunawan, Administrasi Sekolah Administra Pendidikan Mikro (Jakarta: PT Rineka Cipta, 2002), 220-221.

${ }^{20}$ Ahmad Kurnia El-Qarni, Leadershif Dalam Organisasi Perusahaan, (Online). http://www.w3c.org/TR/1999/REC-html. (Diakses 1 Mei 2018) 
tindakan penggerakannya sering mempergunakan pendekatan yang mengandung unsur paksaan dan bersifat menghukum.

Kedua, tipe militeristis. Tipe kepemimpinan militerisme berbeda dengan seorang pemimpin organisasi militer. Seorang pemimpin yang bertipe militeristis ialah seorang pemimpin yang memiliki sifat-sifat berikut: a) Dalam menggerakan bawahan sistem perintah yang lebih sering dipergunakan; b) Dalam menggerakkan bawahan senang bergantung kepada pangkat dan jabatannya; c) Senang pada formalitas yang berlebih-lebihan; d) Menuntut disiplin yang tinggi dan kaku dari bawahan; e) Sukar menerima kritikan dari bawahannya; f) Menggemari upacaraupacara untuk berbagai keadaan.

Ketiga, tipe paternalistis. Seorang pemimpin yang tergolong sebagai pemimpin yang paternalistis ialah seorang yang memiliki ciri sebagai berikut: a) Menganggap bawahannya sebagai manusia yang tidak dewasa; b) Bersikap terlalu melindungi (overly protective); c) Jarang memberikan kesempatan kepada bawahannya untuk mengambil keputusan; d) Jarang memberikan kesempatan kepada bawahannya untuk mengambil inisiatif; e) Jarang memberikan kesempatan kepada bawahannya untuk mengembangkan daya kreasi dan fantasinya; f) Sering bersikap maha tahu.

Keempat, tipe kharismatik. Hingga sekarang ini para ahli belum berhasil menemukan sebabsebab mengapa seseorang pemimpin memiliki karisma. Umumnya diketahui bahwa pemimpin yang demikian mempunyai daya tarik yang amat besar dan karenanya pada umumnya mempunyai pengikut yang jumlahnya yang sangat besar, meskipun para pengikut itu sering pula tidak dapat menjelaskan mengapa mereka menjadi pengikut pemimpin itu. Karena kurangnya pengetahuan tentang sebab musabab seseorang menjadi pemimpin yang karismatik sering hanya dikatakan bahwa pemimpin yang demikian diberkahi dengan kekuatan gaib (supra natural powers). Kekayaan, umur, kesehatan, profil tidak dapat dipergunakan sebagai kriteria untuk karisma. Gandhi bukanlah seorang yang kaya, Iskandar Zulkarnain bukanlah seorang yang fisik sehat, John F Kennedy adalah seorang pemimpin yang memiliki karisma meskipun umurnya masih muda pada waktu terpilih menjadi Presiden Amerika Serikat. Mengenai profil, Gandhi tidak dapat digolongkan sebagai orang yang 'ganteng".

Kelima, tipe demokratis. Tipe kepemimpinan ini memiliki karakteristik sebagai berikut: a) Dalam proses penggerakan bawahan selalu bertitik tolak dari pendapat bahwa manusia itu adalah makhluk yang termulia di dunia; b) Selalu berusaha mensinkronisasikan kepentingan dan tujuan organisasi dengan kepentingan dan tujuan pribadi dari pada bawahannya; c) Senang menerima saran, pendapat, dan bahkan kritik dari bawahannya; d) Selalu berusaha mengutamakan kerjasama dan teamwork dalam usaha mencapai tujuan; e) Ikhlas memberikan kebebasan yang seluas-luasnya kepada bawahannya untuk berbuat kesalahan yang kemudian diperbaiki agar bawahan itu tidak lagi berbuat kesalahan yang sama, tetapi lebih berani untuk berbuat kesalahan yang lain; f) Selalu berusaha untuk menjadikan bawahannya lebih sukses daripadanya; g) Berusaha mengembangkan kapasitas diri pribadinya sebagai pemimpin.

Dalam pandangan Tobroni, kepemimpinan seseorang pada dasarnya tidak dapat ditentukan oleh pangkat, jabatan dan kedudukan orang tersebut. Kepemimpinan muncul bukan dari keindahan luar (eksternal) seseorang (outher beauty of human being), melainkan dari keindahan jiwa (inner beauty of spiritual human being). Kepemimpinan muncul dari suatu proses panjang dan suatu keputusan untuk menjadi pemimpin. Ketika seseorang menemukan keyakinan dasar (core belief) dan nilai-nilai dasar (core values) yang dijadikan pegangan hidupnya, ketika seseorang menetapkan visi dan misi hidupnya, ketika seseorang merasa damai dalam dirinya (inner peace) memiliki karakter yang kokoh (integrasi), ketika ucapan dan tindakannya mampu memberikan pengaruh kepada orang lain secara suka rela, 
ketika keberadaannya mendorong perubahan dalam organisasinya,pada saat itulah seseorang menjadi pemimpin yang sesungguhnya. ${ }^{21}$

\section{Idelisme pemimpin dalam meningkatkan kinerja guru di lembaga pendidikan islam.}

Secara teoritis gambaran idealitas seorang pemimpin, secara umum dapat dilihat baik dari perspektif Barat maupun dari perspektif Islam. Hal ini sebagaimana Fakih dan Wijayanto mampu memaparkan kedua perspektif tersebut. ${ }^{22}$ Menurutnya, sifat ideal seorang pemimpin perspektif Barat adalah: a) memiliki kemampuan mempengaruhi dan membujuk orang lain (inducing); b) memiliki kemampuan manajerial yang baik karena kepemimpinan lebih dari sekedar menduduki jabatan formal; c) memiliki konsep relasi dan menjadi sumber inspirasi bagi orang-orang yang dipimpinnya; d) memiliki visi yang jelas dan mampu menerjemahkan visi tersebut sebagai misi yang dilaksanakan oleh bawahannya; e) memiliki sikap yang optimistis dalam mengemban amanah organisasi; dan f) memiliki intrait approach (pendekatan watak) yang mencolok sebagai hasil dari proses latihan dan pendekatan situasional atau perilaku yang tersimak (observed behavior) bukan pada pembawaan (inborn) yang hipotetikal.

Sedangkan sifat ideal pemimpin dalam perspektif islam adalah sebagaimana berikut: ${ }^{23}$ a) harus mampu memimpin dan mengendalikan dirinya sendiri sebelum memimpin orang lain; b) memiliki kemampuan manajerial yang baik karena seorang pemimpin itu harus dipilih dari kualitas yang terbaik; c) memiliki konsep relasi yang baik karena pemimpin harus mampu menjambatani berbagai perbedaan yang ada di tengah-tangah masyarakatnya; d) visinya adalah Al-Quran dan misinya menegakkan kebenaran; e) memiliki sikap tawadhu dan mawas diri dalam mengemban amanah Allah, karena pada prinsipnya kepemimpinan itu bukan saja harus dipertanggungjawabkan di depan lembaga formal tapi yang penting lagi dihadapan Allah SWT; dan f) memiliki sifat sidiq (benar), amanah (terpercaya), tabligh (menyampaikan apa adanya), fathonah (pandai) serta menyadari sepenuhnya bahwa Allah memberikan kemampuan yang berbeda-beda bagi setiap orang serta menerimanya dengan rasa syukur dan ikhlas.

Berikut ini salah satu gambaran yang perlu dipahami terkait bagaimana seorang pemimpin mengimplementasikan teori-teori dalam kehidupan berorganisasi baik di perusahaan maupun lembaga pendidikan:

${ }^{21}$ Tobroni, The Spiritual Leadership; Pengefektifan Organisasi Noble Industry Melalui PrinsipPrinsip Spiritual Etis, (Malang: UMM Press, 2005), 38.

${ }^{22}$ Aunur Rohim Fakih dan Iip Wijayanto, Kepemimpinan Islam, 32-34.

${ }^{23}$ Ibid, 34 


\begin{tabular}{|c|c|c|c|}
\hline Uraian & $\begin{array}{l}\text { Kepemimpinan } \\
\text { Transaksional }\end{array}$ & $\begin{array}{l}\text { Kepemimpinan } \\
\text { Transformasional }\end{array}$ & $\begin{array}{l}\text { Kepemimpinan } \\
\text { Spiritual }\end{array}$ \\
\hline $\begin{array}{l}\text { Hakekat } \\
\text { kepemimpinan }\end{array}$ & $\begin{array}{l}\text { Fasilitas, Kepercayaan } \\
\text { manusia (bawahan) }\end{array}$ & $\begin{array}{l}\text { Amanat dari sesama } \\
\text { manusia }\end{array}$ & $\begin{array}{l}\text { Ujian, amanat dari } \\
\text { Tuhan dan manusia }\end{array}$ \\
\hline $\begin{array}{l}\text { Fungsi } \\
\text { Kepemimpinan }\end{array}$ & $\begin{array}{l}\text { Untuk membesarkan diri dan } \\
\text { kelompoknya atas biaya orang } \\
\text { lain melalui kekuasaan }\end{array}$ & $\begin{array}{l}\text { Untuk memberdayakan } \\
\text { pengikut dengan } \\
\text { kekuasaan keahlian dan } \\
\text { keteladanan }\end{array}$ & $\begin{array}{l}\text { Untuk } \\
\text { memberdayakan dan } \\
\text { mencerahkan iman dan } \\
\text { hati nurani pengikutu } \\
\text { melalui jihad } \\
\text { (pengorbanan) dan } \\
\text { amal shaleh (altruistik) }\end{array}$ \\
\hline $\begin{array}{l}\text { Etos } \\
\text { kepemimpinan }\end{array}$ & $\begin{array}{l}\text { Mendedikasikan usahanya } \\
\text { kepada manusia untuk } \\
\text { memperoleh imbalan/ posisi } \\
\text { yang lebih }\end{array}$ & $\begin{array}{l}\text { Mendedikasikan } \\
\text { usahanya kepada sesama } \\
\text { untuk kehidupan bersama } \\
\text { yang lebih baik }\end{array}$ & $\begin{array}{l}\text { Mendedikasikan } \\
\text { usahanya kepada Allah } \\
\text { dan sesama manusia } \\
\text { (ibadah) tanpa pamrih } \\
\text { apapun }\end{array}$ \\
\hline $\begin{array}{l}\text { Sasaran tindakan } \\
\text { kepemimpinan }\end{array}$ & $\begin{array}{l}\text { Pikiran dan tindakann yang } \\
\text { kasat mata }\end{array}$ & Pikiran dan hati nurani & $\begin{array}{l}\text { Spiritualitas dan hati } \\
\text { nurani }\end{array}$ \\
\hline $\begin{array}{l}\text { Pendekatan } \\
\text { kepemimpinan }\end{array}$ & Posisi dan kekuasaan & $\begin{array}{l}\text { Kekuasaan, keahlian dan } \\
\text { keteladanan }\end{array}$ & $\begin{array}{l}\text { Hati nurani dan } \\
\text { keteladanan }\end{array}$ \\
\hline $\begin{array}{l}\text { Dalam } \\
\text { mempengaruhi } \\
\text { dan yang } \\
\text { dipimpin }\end{array}$ & $\begin{array}{l}\text { Kekuasaan, perintah, uang, } \\
\text { sistem, mengembangkan } \\
\text { interest, transaksional }\end{array}$ & $\begin{array}{l}\text { Kekuasaan keahlian dan } \\
\text { kekuasaan referensi }\end{array}$ & $\begin{array}{l}\text { Keteladanan, } \\
\text { mengilhami, } \\
\text { membangkitkan, } \\
\text { memberdayakan, } \\
\text { memanusiakan }\end{array}$ \\
\hline $\begin{array}{l}\text { Cara } \\
\text { mempengaruhi }\end{array}$ & $\begin{array}{l}\text { Menaklukkan jiwa dan } \\
\text { membangun } \\
\text { melalui kekuasaan }\end{array}$ & $\begin{array}{l}\text { Memenangkan jiwa dan } \\
\text { membangun karisma }\end{array}$ & $\begin{array}{l}\text { Memenangkan jiwa, } \\
\text { membangkitkan iman }\end{array}$ \\
\hline $\begin{array}{l}\text { Target } \\
\text { kepemimpinan }\end{array}$ & $\begin{array}{l}\text { Membangun jaringan } \\
\text { kekuasaan }\end{array}$ & $\begin{array}{l}\text { Membangun } \\
\text { kebersamaan }\end{array}$ & $\begin{array}{l}\text { Membangun kasih, } \\
\text { menebar kebajikan dan } \\
\text { penyalur rahmat Tuhan }\end{array}$ \\
\hline
\end{tabular}

Tabel 1

Melalui gambaran teoritis di atas maka mau tidak mau kepemimpinan di lembaga pendidikan Islam seperti di sekolah-sekolah Islam (madrasah) handaknya berpijak pada tataran ideologis tersebut. Hal ini seperti ditegaskan kembali oleh Muhaimin bahwa Kepala Madrasah setidaknya mengemban dua tugas penting, diantaranya: Pertama, tugas manajerial, yaitu seorang kepala sekolah dituntut untuk mampu menyelesaikan tugas-tugas administrasi dan supervisi. Kedua, tugas dibidang spiritual, yaitu seorang kepala sekolah dituntut untuk mampu menjadikan madrasah sebagai biah islamiyyah (suasana relijius-Islam) yang mampu megantarkan para anak didiknya menjadi ûlû al-albăb, suatu pribadi yang memiliki kekokohan spiritual, moral, dan intelektual serta profesional. ${ }^{24}$

\section{Kepemimpinan Berparadigma Profetik dalam upaya meningkatkan kinerja guru dan tanggungjawabnya}

Pius A Partanto dan M. Dahlan Al-Barry dalam kamus ilmiah populer mengartikan profetik dengan kenabian. ${ }^{25}$ Sementara itu, "kenabian" atau nabi merupakan "pembawa nubuwat atau utusan Tuhan untuk membawa berita yang maha besar (nubuwat) baik hanya untuk dirinya sendiri atau untuk umatnya". ${ }^{26}$ Pada dasarnya kenabian adalah salah satu wujud kepemimpinan yang diamatkan Tuhan kepada salah seorang yang terpilih di antara umat manusia untuk menjadi pemimpin dan pembina umatnya.

\footnotetext{
${ }^{24}$ Imam Tolkhah dan Ahmad Barizi, Membuka Jendela Pendidikan Islam, Mengurai Akar Tradisi
} dan Integrasi Keilmuan Pendidikan Islam, (Jakarta: PT RajaGrafindo Persada, 2004), 192.

${ }^{25}$ Pius A Partanto dan M. Dahlan AlBarry, Kamus Ilmiah Populer, (Surabaya: Arkola, TT), 627.

${ }^{26}$ Ibid, 506 
Adapun, maksud paradigma profetik dapat dipahami sebagai seperangkat teori yang tidak hanya mendeskripsikan dan mentransformasikan gejala sosial, dan tak pula hanya mengubah suatu hal demi perubahan, namun lebih dari itu, diharapkan dapat mengarahkan perubahan atas dasar cita-cita etik dan profetik. ${ }^{27}$

Menurut perspektif Kuntowijoyo, dalam ajaran Islam terdapat salah satu ayat yang dapat dijadikan landasan yang mengandung muatan misi paradigma profetik yaitu QS. Ali Imran: 110 yang artinya: "Kamu adalah umat yang terbaik yang dilahirkan untuk manusia, menyuruh kepada yang ma'ruf (humanisasi), dan mencegah dari yang munkar (liberasi), dan beriman kepada Allah (transendensi). Sekiranya ahli kitab beriman, tentulah itu lebih baik bagi mereka, di antara mereka ada yang beriman, dan kebanyakan mereka adalah orang-orang yang fasik". ${ }^{28}$

Dari ayat tersebut Kuntowijoyo memandang bahwa misi transformasi sosial yang dilakukan oleh para nabi yaitu melibatkan unsur humanisme, liberasi dan trensendensi. ${ }^{29}$ Dengan demikian, mengikuti alur berpikir Kunto, secara garis besar maka dapat diambil benang merah bahwa misi kenabian apapun yang dilakukannya (termasuk dalam peran kepemimpinannya) tidak terlepas dari tiga unsur tersebut yaitu humanisasi, liberasi dan transedensi.

Walaupun demikian banyak ayat-ayat al-Quran lainnya yang menjelaskan tentang tugas yang diemban oleh para Rasul selaku pemimpin di kalangan internal umatnya. Landasan ayatayat al-Quran tersebut sekaligus untuk menggali paradigma kepemimpinan profetik (kenabian). Di antara ciri-ciri atau paradigma kepemimpinan yang musti dimiliki oleh para nabi atau rasul adalah seperti terungkap dalam ayat-ayat al-Quran, diantaranya:

a. Cerdas, analitis dan kritis (fathanah) terdapat dalam QS. AlBaqarah: 151, artinya: "Sebagaimana (kami telah menyempurnakan nikmat Kami ke-padamu) Kami telah mengutus kepadamu Rasul diantara kamu yang membacakan ayat-ayat Kami kepada kamu dan mensucikan kamu dan mengajarkan kepadamu Al kitab dan Al-Hikmah, serta mengajarkan kepada kamu apa yang belum kamu ketahui". Makna ayat tersebut secara inplisit menjelaskan bahwa kepemimpinan seorang Rasul yang ditugaskan untuk membacakan dan mengajar manusia menuntut dirinya untuk cerdas atau pintar. Sedangkan kemampuan analitis dan kritis tersirat dalam salah satu ayat yang lainnya misalnya dalam QS. Yusuf ayat 55 dan 109.

b. Tabligh, tegas, berani dan menjunjung keadilan dan kejujuran (QS. Al Baqarah: 213), artinya: "Manusia itu adalah umat yang satu. (setelah timbul perselisihan), Maka Allah mengutus Para Nabi, sebagai pemberi peringatan, dan Allah menurunkan bersama mereka kitab yang benar, untuk memberi keputusan di antara manusia tentang perkara yang mereka perselisihkan. tidaklah berselisih tentang kitab itu melainkan orang yang telah didatangkan kepada mereka Kitab, Yaitu setelah datang kepada mereka keteranganketerangan yang nyata, karena dengki antara mereka sendiri. Maka Allah memberi petunjuk orang-orang yang beriman kepada kebenaran tentang hal yang mereka perselisihkann itu dengan kehendakNya. dan Allah selalu memberi petunjuk orang yang dikehendakiNya kepada jalan yang lurus". Tabligh merupakan salah satu misi utama yang diemban oleh para Rasul. Dalam rangka menyampaikan hak-hak Allah SWT maka para rasul dituntut untuk bersifat tegas dan memiliki keberanian. Tegas dan berani dalam menyampaikan kabar gembira berupa pahala atau balasan baik bagi orang-orang yang berbuat baik (amal shaleh). Tegas dan berani dalam menyampaikan peringatan-peringatan Allah SWT berkenaan dengan ancamanancamanNya. Sementara itu, dalam menegakkan hukum Allah SWT selain dituntut ketegasan dan keberanian juga perlu ditunjang keadilan dan

\footnotetext{
${ }^{27}$ Moh. Shofan, Pendidikan Berparadigma Profetik; Upaya Konstruktif membongkar dikotomi Sistem Pendidikan Islam ,(Gresik: UMG Press, 2004), 131.

${ }^{28}$ QS. Ali Imran: 110

${ }^{29}$ Kuntowijoyo, Al-Quran sebagai Paradigma Jurmal Ululumu, Jurnal Ulumul Quran No. 4 Vol, No
} V th. 1994137 
kejujuran dengan tanpa pandang bulu dalam menegakkan hukum tersebut. Ayat lain yang berhubungan dengan keberanian yang harus dimiliki oleh seorang nabi seperti tersirat dalam QS. At-Taubah ayat 33 yang berkenaan dengan keberanian dalam menegakkan agama Allah SWT "Dialah yang telah mengutus RasulNya (dengan membawa) petunjuk (Al-Quran) dan agama yang benar untuk dimenangkanNya atas segala agama, walaupun orang-orang musyrikin tidak menyukai". ${ }^{30}$

c. Lemah-lembut dan kasih sayang (QS. Ali Imran: 159). "Maka disebabkan rahmat dari Allah-lah kamu Berlaku lemah lembut terhadap mereka. Sekiranya kamu bersikap keras lagi berhati kasar, tentulah mereka menjauhkan diri dari sekelilingmu. karena itu ma'afkanlah mereka, mohonkanlah ampun bagi mereka, dan bermusyawaratlah dengan mereka dalam urusan itu. kemudian apabila kamu telah membulatkan tekad, Maka bertawakkallah kepada Allah. Sesung-guhnya Allah menyukai orang-orang yang bertawakkal kepada-Nya". . Ayat lain yang dapat menunjang sikap lemah lembut dan kasih sayang atas model kepemimpinan para nabi adalah seperti tersirat dalam QS. Al-Anbiya ayat 107 dengan terjemahan "Dan Tiadalah Kami mengutus kamu, melainkan untuk (menjadi) rahmat bagi semesta alam".

d. Membawa misi tauhid (transedental) terdapat pada QS. Al- 'Araf: 59 "Sesungguhnya Kami telah mengutus Nuh kepada kaumnya lalu ia berkata: "Wahai kaumku sembahlah Allah, sekali-kali tak ada Tuhan bagimu selain-Nya." Sesungguhnya (kalau kamu tidak menyembah Allah), aku takut kamu akan ditimpa azab hari yang besar (kiamat)". ${ }^{2}$ Ayatayat lain yang memiliki kandungan serupa seperti terdapat dalam QS. Al-'Araf: 65, 73, 85 . ayat tersebut secara inflisit menjelaskan tentang peran transendental kepemimpinan nabi dalam menyeru umatnya untuk beribadah kepada Allah SWT.

Ayat-ayat di atas hanyalah sebagian dari beberapa ayat yang dapat mengindikasikan tugas kepemimpinan para Rasul selaku pemimpin bagi umat-umatnya, sementara itu masih banyak ayat-ayat al-Quran lainnya yang memiliki makna dan kandungan yang serupa. Pada dasarnya karakteristik paradigma kenabian yang terkandung dalam ayat-ayat al-Quran tersebut, relevan dengan empat sifat yang dimiliki oleh kenabian Muhammad SAW yaitu shidiq, amanah, fathanah dan tabligh. Kepemimpinan Muhammad sebagaimana digambarkan oleh Muhammad Syafi'i Antonio mencakup berbagai aspek kepemimpinan, diantaranya: kepemimpinan keluarga, dakwah, bisnis, sosial-politik, pendidikan, hukum dan militer ${ }^{33}$

Sementara itu, Mukhtar Abdullah, dkk, secara inflisit memberikan gambaran yang berupa nilai-nilai esensial yang perlu terimplementasi dalam aktivitas organisasi. Menurut hemat penulis, nilainilai esensial dalam kepemimpinan organisasi yang dipaparkan oleh Mukhtar, boleh jadi dapat dikategorikan sebagai karakteristik paradigma kepemimpinan profetik. Di antara karakteristik (nilai-nilai esensial) tersebut adalah Trustworthy atau amanah (QS. AlMu'minun: 8-10), truthful atau Shiddiq (QS. An-Nisa: 69), fairnes atau 'adl (QS. Al-Maidah: 89), kindness and goodness atau ihsan dan hasanah (QS. Al-An'am: 151), humility atau akhlaq al-karimah (QS. Al-Furqan: 63), patience and perseverance atau sabr (200), forgiveness atau 'afu (QS. Ali Imran: 134), dan tolerance atau samahah (QS. Al-Hujurat: 11). ${ }^{34}$ Kajian tentang nilai kepemimpinan profetik, memiliku korelasi yang erat dengan konsep akhlak seorang pemimpin baik yang diajarkan oleh al-Quran ataupun al-Hadits. Menurut perspektif al-Quran walaupun secara garis besar telah disinggung oleh penjelasan di atas terdapat beberapa ayat

\footnotetext{
${ }^{30}$ QS. At-Taubah: 33

${ }^{31}$ QS. Ali Imran 159

${ }^{32}$ QS. Al-'Araf: 59

${ }^{33}$ Lihat Muhammad Syafi'I Antonio, Muhammad SAW: The Leader Suoer Manager (Jakarta: Tazkia Multimedia \& ProLM Center, 2007), 77-255.

${ }^{34}$ Mokhtar Abdullah, dkk. Value Based Total Performance Excellence Model; Baseline Assessment Criteria Guidlines For Organizations, 23-28.
} 
yang mengajarkan tentang akhlak pemimpin dalam Islam, diantaranya: a) mencintai kebenaran (QS. Al-Baqarah: 147 dan AlMaidah:8); b) Dapat menjaga amanah dan kepercayaan orang lain (Al-Baqarh 166, Al-Mu'minun: 8-9); c) Ikhlas dan memiliki semangat pengabdian (QS. Al-Baqarah: 245); d) Baik dalam pergaulan dengan Masyarakat (QS. Yusuf: 22); e) bijaksana. ${ }^{35}$

Adapun menurut perspektif hadits terdapat beberapa akhlak pemimpin dalam Islam, diantaranya: a) Memimpin untuk melayani bukan dilayani. Pernyataan ini diambil dari salah satu hadits yang bunyi terjemahannya "pemimpin suatu kaum adalah pengabdi (pelayan) mereka. b) Zuhud terhadap kekuasaan. seperti perkataan Rasulullah "kami tidak akan mengangkat orang yang berambisi berkedudukan" (HR. Muslim). c) Jujur dan tidak munafik. Diantaanya berdasarkan hadits "Allah melaknat penyuap, penerima suap yang member peluang bagi mereka" (HR. Ahmad). d) Memiliki visi keumatan (terbebas dari panatisme). Sebagaimana dalam hadits, "ka'ab bin Iyadh ra bertanya; "Ya Rasulullah, apabila seseorang mencintai kaumnya, apakah itu tergolong fanatisme? Nabi SAW menjawab, "Tidak, fanatisme ('Ashabiyah) ialah bial seseorang mendukung (membantu) kaumnya atas suatu kezaliman...". (HR. Ahmad) e) Memiliki tanggung jawab moral. Berdasarkan hadits yang diriwayatkan dalam kitab Al-Muwaththa karya Imam Malik, yang artinya: "Setiap kalian adalah pemimpin dan akan dimintai pertanggungjawan atas kepemimpinnannya. Dan Amir (pemimpin) yang memimpin masyarakat, ia akah dimintai pertanggungjawaban atas kepemimpinannya. Dan seorang lakilaki adalah pemimpin bagi keluarganya dan ia akan dimintai pertanggungjawaban atas kepemimpinannya. Seorang perempuan pemimpin atas harta suaminya dan ia akan dimintai pertanggungjawaban atas kepemimpinannya. Seorang hamba sahaya pemimpin atas harta tuannya dan ia pun akan dimintai pertnggungjawaban ata kepemimpinannya. Kemudian setiap kalian adalah pemimpin dan akan dimintai pertanggungjawaban atas kepemimpinannya". ${ }^{6}$

Jadi dari beberapa uraian di atas dapat disimpulkan, bahwa seorang pemimpin jika mampu melaksanakan menajemen kepemimpinan yang telah dipraktikan oleh rasulullah, penulis optimis dapat tercipta suasana kepemimpinan yang ideal sesuai dengan al-qur'an dan hadist. Sehingga dari proses yang ada akan menggambarkan suasana lembaga/organisasi yang dinamis, efektif, efisien dan kokoh dalam menghadapi segala halang melintang dengan konsep fleksiblelitas dalam segala peradaban.

\section{Kesimpulan}

Dari beberapa uraian di atas maka dapat ditarik benang merah, bahwasanya manajemen kepemimpinan di sebuah lembaga pendidikan islam berjalan dengan baik dan ideal sesuai konsep al-qur'an dan hadits manakala masing-masing di antara mereka mampu mengamalkan nilai-nilai profetik dengan penuh tanggungjawab dalam menjalankan roda organisasinya, sebagai upaya menjawab harapan, keinginan, dan kebutuhan masyarakat.

\section{Daftar Pustaka}

Ahmad Kurnia El-Qarni, Leadershif Dalam Organisasi Perusahaan, (Online). http://www.w3c.org/TR/1999/REC-html. (Diakses 1 Mei 2018)

\footnotetext{
${ }^{35}$ Aunur Rohim Fakih dan Iip Wijayanto, Kepemimpinan Islam, 39-45.

${ }^{36}$ Malik Bin Anas Abu Abdullah AlAshbahiy, Al- Muwaththa Imam Malik, Juz 3 (Damasqus: Darul Qalam, 1991 M/1413 H), 503.
} 
Ary H. Gunawan, 2002, Administrasi Sekolah Administra Pendidikan Mikro, Jakarta: PT Rineka Cipta.

Aynur Pala, The Need For Character Education, dalam International Journal Of Social Sciences And Humanity Studies Vol 3, No 2, 2011 ISSN: 1309-8063 (Online).

Dindin Jamaluddin, Character Education In Islamic Perspective, dalam International Journal Of Scientific E Technology Research, Volume 2, Issue 2, February 2013 ISSN 2277-8616.

E. Rochaeti, Rahayuningsih, Pontjorini dan G.P. Yanti, 2006, Sistem Informasi Manajemen Pendidikan, Jakarta: Bumi Aksara.

Fakih, Aunur Rohim dan Iip Wijayanto. 2001. Kepemimpinan Islam. Yogyakarta: UII Press.

H.A. Malik Fadjar, 1993. Administrasi dan Super Visi Pendidikan, Yogyakarta: Aditya Media.

Hendyat Soetopo, 2001, Manajemen Pendidikan, Malang : Universitas Negeri Malang.

Husaini Usman, 2010, Manajemen : Teori, Praktik dan Riset Pendidikan, Jakarta: Bumi Aksara.

Imam Tolkhah dan Ahmad Barizi, 2004, Membuka Jendela Pendidikan Islam, Mengurai Akar Tradisi dan Integrasi Keilmuan Pendidikan Islam (Jakarta: PT RajaGrafindo Persada.

John M. Echols dan Hasan Sadily, 1996, Kamus Ingris-Indonseia, Jakarta: PT Gramedia, 351. Kemudian, lihat juga Ahmad Kurnia El-Qarni, Leadershif Dalam Organisasi Perusahaan, (Online). http://www.w3c.org/TR/1999/REC-html. (Diakses 1 Mei 2018)

Kuntowijoyo, Al-Quran sebagai Paradigma Jurnal Ulumul, Jurnal Ulumul Quran No. 4 Vol, No V th. 1994137

M. Manullang \& Marihot Amh Amnullang, 2008, Manajemen Personalia, Yogyakarta : Gajah MadaUniversity Press.

Malayu S.P Hasibuan, 2001, Manajemen Dasar, Pengertian dan Masalah, Jakarta : Bumi Aksara.

Malik Bin Anas Abu Abdullah AlAshbahiy, , 1991, Al- Muwaththa Imam Malik, Juz 3 Damasqus: Darul Qalam.

Moh. Shofan, 2004, Pendidikan Berparadigma Profetik; Upaya Konstruktif Membongkar Dikotomi Sistem Pendidikan Islam, Gresik: UMG Press.

Mokhtar Abdullah, dkk. Value Based Total Performance Excellence Model; Baseline Assessment Criteria Guidlines For Organizations, 23-28.

Muhaimin, dkk, 2009,Manajemen Pendidikan :Aplikasi dalam Penyusunan Rencana Sekolah / Madrasah, Jakarta : Kencana.

Muhammad Syafi'i Antonio, 2007, Muhammad SAW: The Leader Suoer Manager, Jakarta:Tazkia Multimedia \& ProLM Center, 77-255.

Nanang Fattah, 2004, Landasan Manajemen Pendidikan, Bandung: PT Remaja Rosdakarya. 
Ngalim Purwanto, 2010, Administrasi dan Supervisi Pendidikan, Bandung : Remaja Rosdakarya.

Pius A Partanto dan M. Dahlan AlBarry, Kamus Ilmiah Populer, Surabaya: Arkola, TT

T. Hani Handoko, 2003, Manajemen, Yogyakarta : UGM.

Tobroni, 2005, The SpiritualLeadership; Pengefektifan Organisasi Noble Industry Melalui Prinsip-Prinsip Spiritual Etis, Malang: UMM Press.

Wahjosumidjo, 2005, Kepemimpinan Kepala Sekolah: Tinjauan Teoritik dan Permasalahannya, Jakarta: PT RajaGrafindo Persada.

Weinata Sairin, 2001,Pendidikan yang Mendidik, Jakarta : Yudhistira. 